\title{
Due To Legal Marriage Without Married Agreement Relating To The Existence Of Bankruptcy
}

\author{
Reza Fahlevi Bachtiar ${ }^{1}$ and Umar ma'ruf ${ }^{2}$
}

Abstract. The problems that will be answered in this study are grouped into two, about how the legal consequences of marriage, held without mating agreement with the bankruptcy, and how the legal standing of the assets of the debtor spouse to mate without mating agreement after bankruptcy. The method used in this research is the empirical jurisdiction. The legal consequences of marriage, held without mating with their bankruptcy agreement is legally valid as the bankruptcy of the husband or wife of the bankrupt debtor. The separation between the property along with a personal wealth does not necessarily separate due to the bankruptcy imposed on married couples who enter into marriage without mating agreement as well as the marriage held by mating or separation agreement treasure. The legal position of property the debtor spouse into marriage without the agreement having been declared bankruptcy mating separated into two parts, namely the unity property and personal possessions. Husband or wife treasure the bankruptcy debtor entered into treasure union declared legally bankrupt as a result of participating bankruptcy imposed against the partner.

Keywords: Effects; Marriage; Marriage Agreement; Bankruptcy.

\section{Introduction}

Marriage is an inner and outer bond between a man and a woman as husband and wife with the aim of forming a happy family. Grounds of marriage is love each other, mutual acceptance of advantages and disadvantages of each, mutually accept what is. Because they are beings coming from different lifestyles, they come from two types of characters, character, temperament, behavior, habits of two different families. Therefore, mutual love each other then there was a marriage. After they married, and as husband and wife, they have the burden imposed by the Act, namely the obligation to bear a noble, they have rights and obligations are balanced or equal in domestic life. In social life in the community, they should not be allowed to restrain each other, blocking each other. They have the right to take legal actions. ${ }^{3}$

In terms of legal relationships, marriage only be seen in terms of course, as to which is set in Article 26 of the Civil Code which is: "Act only in regard to marriages civil relations".

Settings on the marriage when the review of the draft Civil Code, especially regarding the assets can be divided into two kinds, namely, the unity of marriage with wealth and marriage with the separation of wealth.

Marriage held by mating agreement have different effects with the marriage took place without the mating agreement of wealth, both to assets acquired before marriage or innate property or property acquired after the marriage took place. Meanwhile, when viewed from the common law, customary law does not recognize the agreement to marry. Mating Treaty itself in western society has an individualistic character and capitalistic. Individualistic, because through mating agreement recognizes the independence of the

\footnotetext{
${ }^{1}$ Student of Master Program (S2) of Notaries Faculty of Law UNISSULA Semarang Indonesia email : bachtiarreza04@gmail.com

${ }^{2}$ Lecturer of Faculty of Law UNISSULA

${ }^{3}$ Martimam Projohamidjojo 2011 Hukum Perkawinan Indonesia Karya Gemilang Jakarta p. 31.
} 
treasure husband and wife treasure. Capitalistic because the goal is to protect households from bankruptcy in the business world, which means that when one of the parties between husband and wife filed for bankruptcy, the other can still be saved. ${ }^{4}$

Basically, the purpose of mating agreement made is to protect the assets of the husband or the wife, ie, as a preventive action to anticipate conflicts and strife in the future.

The instrument can be used to manage the assets in the marriage and prevent conflicts that may arise is to make arrangements to marry. ${ }^{5}$ Unlike the marriage took place without the mating agreement Berlakulah rounded unity against the marital property or with other terms, also known as community property.

In practice, it is not possible for a debtor-bound legal marriage had debts to more than one creditor, thus, when debtors fail to pay off debts to creditors is more than one, then all the assets will be sold for debt repayment to creditors is more than one such. But at the time of the distribution of wealth from the sale of the debtor, it would be very likely to happen there is much disagreement among creditors to get repayment on its accounts receivable. ${ }^{6}$

Difference in meaning of unity property of the marriage or property that referred to by the Code of Civil Code with the Marriage Law, as well as the provisions which one should be applied specifically to bankruptcy happens to assets such marriages, encourage researchers to examine and understand the reasons for the application of the more effective.

Based on the description above can be formulated problems of the legal consequences of marriage How held without mating agreement with the bankruptcy?, and How the legal position of the assets the debtor spouse to mate without mating agreement having been declared bankrupt?

\section{Research Methods}

The method used in this research is empirical juridical, Legal Research empirically research methods to obtain primary data and find out the truth by using inductive thinking and criterion of truth correspondents as well as the fact that is used to perform the induction process and testing truth correspondent is fact edge. ${ }^{7}$

\section{Result And Discussion}

Marriage in the draft Civil Code be seen only in civil relations, as stipulated in Article 26 of the Civil Code. Thus, the marriage is valid, if the marriage did qualified specify in the draft Civil Code.

According to the Law of Civil Law, in principle, in a marriage there is only one treasure is treasure unity. If the prospective spouses want to deviate this principle can be done by making an agreement mating. In addition to the prospective spouses, deviation from this

4 Soetojo Prawirohamidjojo 2002 Airlangga University Press Airlangga University Press Surabaya p. 4.

${ }^{5}$ Yunanto 2013 Perjanjian Pra Nikah dan Harta Kekayaan Perkawinan Dalam Teori dan Praktik Semarang p. 12.

${ }^{6}$ Is Ikhwansyah et.al 2012 Hukum Kepailitan Analisis Hukum Perselisihan dan Hukum Keluarga Serta Harta Benda Perkawinan Keni Media Bandung p. 5.

7 Soerjono Soekanto \& Sri Mamudji 2011 Penelitian Hukum Normatif (Suatu Tinjauan Singkat) King Grafindo Persada Jakarta p. 14. 
principle can also be done by the will of a third party, in the case of spouses received an inheritance or grants from third party determines that the property inherited or donated will not be entered into the union (Article 120 of the Civil Code). Therefore, the prospective husband and wife who will enter into marriage should determine early on whether it will be made an agreement to marry or not. ${ }^{8}$

From the above presentation can be concluded as a result of marriage law, which was held without agreement mating of wealth when viewed from the standpoint of the draft Civil Code, that the holding of marriage for the sake of law prevails unity possessions husband and possessions wife unanimously with all the legal consequences. In order to deviate the provisions of the unity round such property, before the marriage took place should be first made the marriage covenant made in the form of a notarial deed.

Act No.1 of 1978 About Marriage is a marriage arrangement that is intended to natives, while the eastern group and foreign of Tionghoa remain on the rules of marriage that are in Book One Chapter Fourth Book of the Law of Civil Law About Marriage. For the indigenous groups that are subject to the Code of Civil Code still allowed to use the rules contained in the Book of the Law of the Civil Law.

Definition of marriage if the terms of Act No. 1 of 1974 About Marriage is, marriage is a bond physically and mentally between a man and a woman as husband and wife with the aim of forming a family or household happy and everlasting based on God, this understanding as which is set in Article 1 of the Marriage Law.

According to the Law of Civil Law, marriage is only seen from the relationship civility alone, then the assets of a marriage can be distinguished, namely, judging from how where the marriage was celebrated. Marriage held by mating agreement may deviate the legislation surrounding the marital property as far as not contrary to morals or to public order. This means that the marriage could take place by splitting the assets between husband and wife.

The concept of unity property according to the Marriage Law is split between private property with treasure unity. Thus we can conclude, that the Marriage Law of personal property or property derived from gifts and inheritance is not legally enter into a marriage union property although not strictly separated in mating agreement.

Separation of possession of personal property premises joint property in marriage without agreement mating according to Marriage Law in line with segregation of assets in a marriage that took place with the agreement of mating, but due to marriage without agreement mating with mating using the agreement to marry still makes no difference legally, it can we see if one of the spouses is declared bankrupt by the Commercial Court.

Bankruptcy happens to marriages that take place without the agreement when viewed from the standpoint of Marriage Act No.1 of 1974 would not have an impact on the whole of the treasure of marriage, because the concept of unity property in this Act does not incorporate the wealth of conjugal unanimously, but separates private property with the property although not held covenant marriage mate.

Bankruptcy declaration imposed against the husband or wife is bound marriage without mating agreement, applies as the bankruptcy of her partner. However, the property included in the bankruptcy estate are treasure unity of marriage, whereas assets owned before the marriage and property acquired from a gift or inheritance husband or wife debtor bankrupt is not the one entered into the bankruptcy estate, since the concept of

8 Yunanto op.cit p. 65. 
unity property according to the Marriage Act No.1 1974 was a separate personal property to community property, as well as affirmed in Article 62 paragraph (1) Labor Law-PKPU. Debtors who legitimated marriage later divided bankruptcy, as long as there is no and can not prove their mating agreement, the bankruptcy declaration also applies to the spouse of the insolvent debtor, regardless of the bankruptcy petition filed by the debtor itself or by its creditors.

A bankruptcy petition filed by the debtor, if the debtor is bound to take place without the agreement of marriage mate then the debtor must be approved by his or her spouse, as set out in Article 4 paragraph (1) Labor Law-PKPU. Because if a bankruptcy petition is granted, then the bankruptcy would also apply to the spouse, so that the declaration of bankruptcy petition filed by the debtor can not be accepted by the Commercial Court without consent if the husband and wife.

According Erin Damanik bankruptcy dropped right to debtors, which if the debtor is bound to valid marriage without the agreement of separation of property or married in unity property, then bankruptcy is also valid on the wife or husband debtor bankrupt them, in which intended of article Article 64 paragraph (1) Labor Law-PKPU; bankruptcy spouses married in unity property, shall be treated as the property of unity bankruptcy.

It can be excluded if it can be proved that in the marital separation agreement property or mating. A bankruptcy petition filed by creditors, either to the husband or wife of the only, or to both, if the bankruptcy petition is granted, bankruptcy also applies to assets marriage united both the husband and wife.

The position of the husband or wife of the debtor bankrupt who enter into marriage without the agreement of mating, by operation of law applies as well as the bankruptcy of the husband or wife of the debtor bankrupt, so that if one of the spouses who enter into marriage without the agreement mating declared bankrupt by the Commercial Court of the bankruptcy is kepailtan against their marital property.

Property in a marriage without separation of property or without mating agreement according to Act No.1 of 1974 distinguished on private property and common property. Personal property is property derived from gifts or grants and property obtained from inheritance. While the community property is property acquired during the marriage took place.

Marriage Law automatically distinguish between personal property and property assets together, even if there is no separation agreement treasure. However, in case of bankruptcy it is not necessarily able to separate due to the bankruptcy of the husband to the wife. Bankruptcy imposed both against the husband and wife would still remain in force as a bankruptcy to both and to treasure their unity.

Treasures acquired during the marriage takes place that is not a property acquired by gift or inheritance from his wife or the debtor bankrupt, treated as the bankruptcy estate to pay off debts for debtors.

Treasure obtained from a gift or inheritance according to Wenang Lane Noto, in the process of the bankruptcy estate will be made to match treasures. Treasure earned by the husband or the debtor bankrupt of gift or inheritance must be proven authentic. If proved, there is a treasure obtained from gifts or grants evidenced by the deed of grant and property obtained from inheritance can be evidenced also by deed of inheritance, the treasures that can be excluded from the bankruptcy estate. 
Their treasures pledged as collateral, whether fiduciary, encumbrance, lien, mortgage or right of collateral on other materialistic, the right holders are taken as creditors separatists and against creditors separatists enforced as if nothing happened bankruptcy.

Treasures that serve as collateral if such property is the personal property of the husband or wife of the debtor bankrupt, the property which is not entered into the bankruptcy estate, then to the holders the right holder of the collateral is enforced as if no bankruptcy or in matching the debt can be used as a creditor separatist. For owners of receivables other than the separatist creditors then naturally they will serve as concurrent creditors, as to which is regulated in Article 1131 and 1132 Book of the Law of Civil Law.

In Article 64 paragraph (3) Labor Law-PKPU stipulated that in the case of a spouse who is declared bankrupt excluding unity property objects, the objects including the bankruptcy estate but can only be used to pay personal debts or husband is declared bankrupt.

Personal property not only includes property of husband and wife are in unity property, but also includes the entire conjugal wealth outside the union, provided that: ${ }^{9}$

- Against deeds done for the sake spouses together, with not care who did it, which is the bankruptcy estate is a treasure union or joint property.

- Acts against the husband or wife do for its own sake, which is a property of the bankruptcy estate is an innate property of each husband and wife.

Position property of bankruptcy debtor spouse, if viewed from the concept of separation of private property with the property where the sense of unity together as treasure under the laws of Marriage No. 1 of 1974, the Bankruptcy Act also separates due to the bankruptcy of the treasures. Treasure that is the bankruptcy estate are treasures that belong to the union of marital property, being on private property is only responsible for the extent of legal making acts of each spouse. In other words eventhough due to the bankruptcy of insolvent debtors as well as bankruptcy applies to the spouse but the treasure that can be entered into the bankruptcy estate was the only treasure unity of marriage.

\section{Closing}

\subsection{Conclution}

- The legal consequences of marriage which took place without the mating agreement with the bankruptcy:

- Bankruptcy imposed on debtors who are bound marriage without separation of property or without mating agreement, a legally valid as the bankruptcy of the husband or wife of the bankrupt debtor, so bankruptcy is enforced against the property of their marital union.

- According to Act No.1 of 1974 About Marriage, treasure marriage is divided into treasure unity of marriage and personal property, so that in case of bankruptcy of the husband or wife of the treasure unity of their marriage declared bankruptcy estate, but the personal property of the husband or wife of the debtor bankrupt can excluded from the bankruptcy estate.

- The legal position of wealth debtor spouses to mate without mating after being declared bankrupt agreement:

\footnotetext{
${ }^{9}$ Is Ikhwansyah et.al op.cit p. 38.
} 
- Treasure from the husband or wife of the debtor's bankruptcy declared which included the bankruptcy estate is treasure their marital union. Treasure unity of marriage is a treasure earned or acquired during the marriage took place.

- Personal property of the husband or wife of the debtor's bankruptcy declared can be taken back or not go into the bankruptcy estate. Personal property is the default property and property obtained from a gift or inheritance. Treasure obtained from a gift or a grant and must be proven heritage in an authentic manner so that the property can be excluded from the bankruptcy estate.

\subsection{Suggestion}

- Marriage law marriage union split between property with private property, but it can not avoid the impact of the bankruptcy happened to your husband or wife is bound for bankruptcy debtor without the agreement of marriage mate. In order to avoid bankruptcy occurring due to the husband or wife is bound legitimate marriage before marriage then it should be held first made the agreement to marry, so that later on in the event of bankruptcy, the bankruptcy only applies to a husband or wife. The mating treaty must be made authentic by a competent authority, namely the notary.

- Treasure of husband and wife hold mating agreement that entered into the bankruptcy estate is a treasure of unity alone, while personal property can be taken back. So that private property is not entered into the bankruptcy estate should be proven premises evidence. Therefore it is better if the gain treasure of gifts or grants, the legal act should be made authentically with the grant deed by a notary. So also with the acquisition of property by inheritance should be done in an authentic manner with inheritance deed made by the notary.

\section{References}

[1] Martiman Projohamidjojo 2011 Hukum Perkawinan Indonesia Jakarta: Karya Gemilang.

[2] Soetojo Prawirohamidjojo 2012 Pluralism Dalam Perundang-Undangan Perkawinan Di Indonesia Surabaya: Airlangga University Press.

[3] Yunanto 2013 Perjanjian Pra Nikah dan Harta Kekayaan Perkawinan dalam Teori dan Praktik Semarang: Madina.

[4] Isis Ikhwansyah et.al 2012 "Hukum Kepailitan Analisis Hukum Perselisihan dan Hukum Keluarga Serta Harta Benda Perkawinan Bandung: Keni Media.

[5] Soerjono Soekanto \& Sri Mamudji 2011 Penelitian Hukum Normatif (Suatu Tinjauan Singkat) Jakarta: Raja Grafindo Persada.

[6] The Book of the Civil Law (Civil Code)

[7] Act No.1 Year 1974 About Marriage

[8] Act No.37 of 2004 on Bankruptcy and Suspension of Payment 